\title{
Urban Vulnerability Reduction: Regulations and Beyond
}

\author{
V. Thiruppugazh \\ Department of Social and Political Change \\ Research School of Pacific and Asian Studies \\ Australian National University- Canberra
}

This article examines the causes of urban earthquake vulnerability in Gujarat, based on the case study of Ahmedabad city which was affected in the 2001, Gujarat earthquake. This paper argues that the non-compliance of regulations which causes urban vulnerability cannot be corrected merely by additional regulations or increased enforcement. An enabling environment of compliance of regulations can be achieved only though good enforcement mechanism, integration of development with vulnerability reduction, good governance practices, awareness creation, partnerships and capacity building.

\section{Keywords:}

urban vulnerability, risk reduction, vulnerability reduction, earthquake vulnerability, regulations, mitigation

\section{Introduction}

Is willful non-compliance of regulations the basic cause of urban vulnerability for earthquakes in Gujarat? This paper will focus on the causes of urban vulnerability in Gujarat, based on the lessons learnt in the recent Gujarat earthquake, through a case study of Ahmedabad.

The world is steadily becoming urban (Boulle, Vrolijks, and Palm 1991).The UN report (2004) on world urbanization prospects projects that more than 50 percent of the world's population will be dwelling in cities and almost all the growth of the world's population between 2000 and 2030 is expected to be absorbed by the urban areas of less developed regions. According to UN projections, the urban population in Asia is expected to become nearly double and the percentage of people living in urban areas in India will be 41.4 against the current figure of 28 percent.

Urbanization process increases vulnerability to natural disasters through the concentration of people and assets (Quarantelli 2003). The increasing urban risk (Wamsler 2006) results in vicious circle of disasters affecting urbanization and urbanization affecting disasters (Pelling 2003). The risk in urban centers is compounded due to unplanned urbanization, development within high risk zones, lack of adherence to building codes (GSDMA 2006), deficient urban management practices, and inappropriate construction practices (Lewis and Mioch 2005) 
In India more than 57 percent of the land is prone to earthquakes and 38 cities each with more than 500,000 population are in the seismic zones of III, IV and $V^{1}$ (UNDP 2002). Reduction of urban vulnerability for seismic hazards is one of the priorities of the national and state governments in India. Gujarat is one of the most urbanized states in India. Nearly 37 percent of the population of Gujarat is urban (Census Commission of India 2001). Ahmedabad, the business capital of Gujarat with a population of more than five million, and five other cities with a population nearly a million or more are situated either in seismic zone III or IV. As the entire state of Gujarat is prone to seismic hazard there is no urban area in Gujarat not vulnerable to earthquakes. In the past 339 years, earthquakes have occurred 19 times in Gujarat, of which 8 were of magnitude 6 and higher on Richter scale (GSDMA 2005a).

This paper aims to analyze some of the issues related to urban vulnerability in detail to arrive at strategies that are necessary to support the development of urban areas in Gujarat and India. The next section investigates briefly the causes and issues related to urban earthquake vulnerability in Ahmedabad. Section III deals with the lessons learnt from the Gujarat earthquake and vulnerability reduction initiatives undertaken. Section IV discusses the existing gaps and the lessons learnt. Section V concludes.

\section{Urban Earthquake Vulnerability}

\section{$2.1 \quad$ Gujarat Earthquake}

On January 26, 2001, one of the most destructive earthquakes ever to strike India occurred in the Kutch region of Gujarat at $8.46 \mathrm{am}$. The damage was spread in an area of $400 \mathrm{kms}$ radius from the epicenter. The official magnitude of the earthquake is 7.7 on the moment $(\mathrm{Mw})$ scale. The epicenter was located near the village of Chaubari, about $20 \mathrm{kms}$ to the north of Bhachau town in Kutch district. Over 7000 villages, Ahmedabad city and 14 municipal towns were affected in the earthquake (GSDMA 2002a). The official death figure is 13,805. About 215,000 houses collapsed fully and 928000 houses were damaged partially (Mishra 2004:58). In the urban areas affected by the earthquake 26726 houses fully collapsed and 213,158 houses were partially damaged (GSDMA 2007). Table 1 briefly shows the human response to major earthquakes.

Ahmedabad city with an area of $1300 \mathrm{Km}^{2}$ has a population of more than 5 million (including urban agglomeration) and a population density of $18420 / \mathrm{Km}^{2}$. Ahmedabad has a literacy rate of $80 \%$ which is the highest in Gujarat. Approximately 440,000 people live in slums (Government of India 2007). The development responsibility within the Municipal Corporation limit is with Ahmedabad Municipal Corporation (AMC) and the development in the urban agglomeration is with Ahmedabad Area Development Authority (AUDA).

\footnotetext{
${ }^{1}$ India is divided in to four seismic zones based on the seismic hazard in ascending order of risk.
} 
Table 1: Human response to major earthquakes

\begin{tabular}{|c|c|c|c|c|}
\hline Stage & Time & Event & $\begin{array}{l}\text { Reaction } \\
\text { Positive }\end{array}$ & Negative \\
\hline 1 & $0-1$ Min & Major earthquake & & Panic \\
\hline 2 & $1 \mathrm{~min}$ - I week & After shocks & Rescue and survival & Fear \\
\hline 3 & 1 week - 1 month & Diminishing & Short term repairs & $\begin{array}{l}\text { Allocation of blame to builders, } \\
\text { designers, officials etc }\end{array}$ \\
\hline 4 & 1 month - 1 year & & $\begin{array}{l}\text { long term repairs } \\
\text { Action for higher standards }\end{array}$ & \\
\hline 5 & 1 year - 10 years & & & Diminishing interests \\
\hline 6 & $\begin{array}{l}10 \text { years - next } \\
\text { earthquake }\end{array}$ & & & $\begin{array}{l}\text { Reluctance to meet seismic } \\
\text { provisions non-compliance with } \\
\text { regulation }\end{array}$ \\
\hline 7 & Next earthquake & & & Repeat stages $1-7$ \\
\hline
\end{tabular}

Source: (Key 1990)

The mega city of Ahmedabad tops the list of cities in composite risk and vulnerability ranking of cities in Gujarat based on base rock motion, surface amplification, liquefaction potential, slope failure potential, building vulnerability, demographic factor, and socioeconomic factor (Oyo Corporation 2004).

Researchers, experts and reconnaissance teams arrived in large numbers to study the causes of the disaster and offered a range of solutions. Jain commenting on the Indian earthquake problem writes:

Quite often, our national or professional pride comes in the way of stating the problem as they are, leading to a loss of opportunity for finding a solution. Every stakeholder thinks that his role is the most crucial in addressing an issue. Hence, differences of opinion are expected between scientists, engineers, administrators, social scientists, and NGOs on how to solve the problem. (Jain 2002)

\subsection{Causes of vulnerability: pre-earthquake Scenario}

It is argued that in Gujarat a seismic hazard was turned in to a massive disaster by political and bureaucratic failures (Wisner et al. 2004). The failure of buildings in Ahmedabad is attributed to : inadequacy for seismic safety and non-compliance of building codes (EERI 2002; Mistry, Dong, and Shah 2001; Menum and Mistry 2001),substandard construction and callous contractors and builders (Times of India 2001), and lack of regulation and enforcement of building codes (Yates 2002), poor quality of construction (EERI 2002:164) and poor quality of material (Goel 2002). Other causes of vulnerability were aging building stock (Wisner et al. 2004), lack of training and education in earthquake design and construction (EERI 2002), and not having a professional engineering association (Mistry, Dong, and Shah 2001). Most of the causes attributed for the urban earthquake vulnerability in Gujarat, such as lack of building safety enforcement, lack of land use planning, and lack of: design, inspection, plan review, and material quality , and lack of insurance are similar to those attributed to the urban earthquake disasters in Turkey, Greece ,Taiwan (Shapiro et al. 2000) and many other countries. 
The numerous studies, reconnaissance reports and fact finding missions which pointed out mainly the technical reasons for the failure of buildings in Ahmedabad, did not address adequately the role played by the market, issues related to urban development, and problems with development control regulations.

\subsection{Regulation and Responsibility}

There are two ways of addressing the causes of vulnerability. One is through the regulatory mechanism and the other is through responsible behavior. It is recognized that the two are not mutually exclusive, however research articles, reports and evaluations done on Gujarat earthquake mainly conclude that lack of regulation and enforcement as the main reason for collapse of buildings in Gujarat in general and Ahmedabad in particular (EERI 2002; Goel 2002; GSDMA 2002a; Jain 2005; Menum and Mistry 2001; Mistry, Dong, and Shah 2001; Murty et al. 2005; Wisner et al. 2004). The Indian Standard code IS 1893-1984 is quite advanced and similar to seismic design found in advanced countries but the seismic design provisions are not mandatory (EERI 2002; Menum and Mistry 2001).IS codes are not mandatory and it is up to the concerned Urban Development Authorities or Municipal Corporations to include the IS codes as mandatory provisions in their by-laws.

It is difficult to pinpoint exactly who is responsible for lack of enforcement of the regulations. This problem is not unique to Gujarat or India. Hazard mitigation occurs in a morally diffused environment- that is in answering the question who is responsible for safety and mitigation, at least in the United States there is no simple or clear answer. In a sense , everyone is responsible and no one is (Godschalk et al. 1999). In a morally diffused environment the responsibility should be shared among the regulators, builders, architects, engineers, and consumers. The complex market of real estates, plethora of acts and regulations and technical nature of safety requirements do not provide a level playing field to all the stakeholders.

In the Municipal corporation areas and particularly in the Ahmedabad Municipal Corporation area, according to the General Development Control Regulations (GDCR), ${ }^{2}$ the developer has to submit a certificate of undertaking duly signed by the structural engineer to design for the hazard safety requirements based on the soil conditions while applying for building permission (AUDA 2004). Thus there is an indirect system of compliance of building codes (EERI 2002: 334) through self regulation. Thus structural safety is the responsibility of the builder/ developer not the municipal engineers ${ }^{3}$. Many builders and professionals accept that it is not the duty of the municipal engineers to ensure quality in private constructions and it is the responsibility of the site engineers, and builders. Bimal Patel, a leading architect commenting on the responsibility of municipal engineers says:

When Municipal engineers are not the executing authority, given the large scale construction activity in Ahmedabad, it is unrealistic to expect a municipal engineer to stand at the construction site to ensure quality. More over as local authority, AMC should be concerned about public good and should take adequate care to ensure safety in places of public access. The private dwellings should be the responsibility of the developers, owners and builders (Patel 2007a).

\footnotetext{
${ }^{2}$ The General Development Control Regulations are framed under Gujarat Town Planning and Urban Development Act which regulates all development in the urban areas.

${ }^{3}$ According to the GDCR, the town development department verifies only the ownership, plot number, right of the owner, and building by-laws related FSI etc.
} 
The system of self regulation, though did not fail completely, resulted in large scale noncompliance of building codes by the private developers and builders. Large number of engineered and traditional structures withstood the earthquake, providing the proof that good construction practices existed (Mistry, Dong, and Shah 2001). When many private buildings collapsed in the earthquake, not a single government building collapsed in Ahmedabad. Most of the government departments handling building construction would tend to follow the codes (EERI 2002:333) due to the fact that there is an elaborate mechanism with rules, approval protocols and procurement procedures in government for construction of buildings. There are three types of errors attributed to unsafe building construction: error of intention, error of ignorance and error of execution. The error of intention does not apply to government departments, for there is no motivation for government engineers to intentionally underdesign and compromise with safety when the cost of construction is met with government funds (Jain 2007). Government authorities followed the building codes even though there was no external enforcement agency. The error of intention plays a major role in private constructions resulting in unsafe building stock.

EERI recovery reconnaissance report on earthquake rebuilding in Gujarat captures clearly the lack of professional ethics of engineers:

There is an unspoken rationalization that is acceptable practice for structural engineers to design differently for private builders than for the government. Builders pressure engineers to cut costs, while government agencies do not. If one engineer refuses to supply a builder with a structural design using lower quality of materials, another will agree to do so (Murty et al. 2005).

One of the examples cited by many for lack of professional ethics among the engineers is the widely prevalent practice of registered structural engineers signing the certificates and drawings prepared by unregistered structural engineers for money undermining the system of accountability. ${ }^{4}$

Housing development in Gujarat, particularly in big cities, is entirely in the hands of private developers. Increase in urban population and demand for prime urban space create enormous pressure on the land in and around the business district resulting in not only skyrocketing of the land prices, but also unregulated growth in hazard prone areas. Housing market in cities is based on "Bankable Schemes". For the huge middle class, purchase of a house or flat is the realization of a life time dream facilitated by bank loan and borrowings, and the cost of the house is a major consideration not the safety norms. Cutting corners due to competition is one of the reasons for developers diluting the quality and preferring cheap designs. The building industry is largely controlled by development and real estate interests who strive to keep costs down (Comerio 1998), and Gujarat is no exception. Yates commenting on the cost cutting practices writes:

If customers do not know about an earthquake code or don't understand the benefits to the customer or community of following it, then there will be no market preference for designers and builders to follow it. An even worse outcome occurs if there is a cost advantage by not following the code. The result is that companies do not follow the code. And if a company does, then the market will penalize it for doing so (Yates 2002).

\footnotetext{
${ }^{4}$ AMC has a system of annual registration of engineers and architects. Certificate of undertaking can be given by only a registered structural engineer.
} 
According to Anil Bakeri, a leading developer in Gujarat:

Out of the 130 buildings which collapsed in Ahmedabad only two high rise buildings collapsed and the remaining buildings were mostly low rise buildings with ground plus three or ground plus four stories. It is estimated that there are about 7000 such buildings in Ahmedabad but less than one percent of the buildings collapsed. If one considers the fact that more than 98 percent of the buildings which were not designed to the seismic safety norms survived, then the reasons for failure should be lack of quality rather than unsafe design. Builders are entirely responsible for poor quality of construction. (Bakeri 2007)

\section{$2.4 \quad$ Regulation and awareness}

One of the reasons for lack of demand for seismic safe houses is the lack of awareness on the part of stakeholders regarding the seismic hazard and vulnerability which existed in Ahmedabad. Before Gujarat earthquake, though many earthquakes have occurred in India in the recent past except Jabalpur earthquake 1997, all others occurred in the rural areas. Latur earthquake affected mainly the rural districts of Latur and Osmanabad. In Latur earthquake, which occurred in 1993, though the damage and destruction was massive, mostly nonengineered stone masonry houses in rural settlements, where buildings construction is entirely in the hands of local artisans with limited skills collapsed (Jain, Murty, and Chandak 1994). In Jabalpur earthquake, though urban, only 38 people died and 8546 houses collapsed (Jain et al. 1997).Jabalpur earthquake did not have significant impact on the general population and the media.

The fact that in the city of Ahmedabad, which lies $300 \mathrm{kms}$ from the epicenter, more than 70 multi-storey buildings collapsed (Vatsa 2001) came as a rude shock to many. Ahmedabad registered second largest death figure of 752 , next only to district Kutch ${ }^{5}$ which registered a death figure of 12,221 (Mishra 2004). In Gujarat earthquake, people witnessed large scale collapse of multistoreyed Reinforced Cement Concrete buildings, multi-storey buildings collapsing like pack of cards and pucca buildings razed to ground. For the first time in India the urban population, media and governments woke up to the existing urban vulnerability for earthquakes. In the pre-earthquake market, seismic safety did not count.

Indian society is not a safety conscious society. For example, despite the fact that about 100,000 die every year in road accidents and more than 360,000 road accidents take place every year (National Crimes Record Bureau 2007), wearing of helmet is still not compulsory in many states. In the states where it is compulsory, there is gross violation. ${ }^{6}$ Exemptions from the law are always sought in the name of religion or gender. It is unrealistic, therefore to expect that those who are not concerned about safety in issues of every day risk will show concern about seismic safety for earthquakes which have a return period of hundred or two hundred years. Lack of civil society and advocacy groups concerned with disaster mitigation is one of the reasons for low public awareness.

\footnotetext{
${ }^{5}$ Kutch district was the epicenter of the earthquake and hence the deaths in Kutch were more than the death in other districts.

${ }^{6}$ Exemptions from the rule are sought in the name of religion or gender. The fact that recently a group of lawyers protested against the rule and there were wide protests by public against the rule speaks volumes about the lack of safety consciousness among public in India.
} 


\subsection{Regulation and Confusion}

As mentioned the multiple actors in urban development process are governed by regulations not always updated to current scenarios. As a result there are loopholes in the system and in the GDCR which could be manipulated. The open spaces and balconies which were not counted for Floor Space Index (FSI) were later covered and converted in to living space by the owners. This lead to the emergence of "floating" column concept wherein the columns of the floors above the first floor terminated at the first level, and did not go directly to the foundation resulting in a major compromise in the integrity of the structure. There is no distinction between the buildings built for self use by the owners and constructions done by real-estate developers. Multiplicity of enabling legislations and enforcement agencies has resulted in lack of clarity of roles and responsibilities. The capacity of enforcement agencies has not been evaluated before formulation of regulations. Lack of accreditation of laboratories, lack of a due process for fixing responsibility for building failures, lack of timely revision of GDCR making it outdated, poor and ambiguous drafting of some of the provisions providing scope for multiple interpretations, lack of consideration of the market forces are some of the basic reasons for violations of safety norms and unregulated development (Patel and Walker 2002).

In order to address the problems in GDCR, one also has to address the problems in Gujarat Town Planning and Urban Development Act (GTPUDA). The Act needs revision with respect to division of responsibility between Government and local authorities, licensing of professionals, scope of development regulations and many other provisions. There are also authorities such as Area Development Authority, Industries Development Authority, and Notified Area Authority, etc creating regulatory overload on the government.

\section{Vulnerability reduction: post- earthquake scenario}

The lessons learnt included the need for: better regulatory control and enforcement mechanism, integration of development with disaster mitigation, transparency and accountability in the system, capacity building and training, information, education and community outreach activities to create awareness among public.

Paradoxically, disaster can also be an opportunity (Lewis and Mioch 2005). Every major disaster opens a window of opportunity (see Table 1), for initiating disaster risk reduction measures. The shattering of the illusion of safety of the cement concrete jungle in Ahmedabad city and large scale devastation in many towns and villages, the experience of International funding organizations, media pressure, terms and conditions of the donors or funding organizations, availability of funds for risk reduction and capacity building measures, and the lessons learnt in the disaster facilitate new policy formulation and creation of technolegal regimes for vulnerability reduction. Government of Gujarat took advantage of the window of opportunity, and initiated a number of activities for vulnerability reduction and long term disaster management in Gujarat.

In order to improve the engineering skills in the state the syllabus of the engineering curriculum was revised to include earthquake engineering as part of the civil engineering syllabus. Training of teachers of engineering colleges, engineers in government and municipal corporations, and masons were undertaken. More than 29000 masons and 6000 engineers have been trained. Competency based certification of masons was introduced. 
Guidelines for construction of earthquake resistant houses using locally available material and low cost material have been prepared by Gujarat State Disaster Management Authority (GSDMA). Insurance awareness drives and seismic safety awareness campaigns through print and electronic media were also undertaken many times. Home owner's guide for seismic safety was published and made available to public at large to educate them on the basic requirements of seismic safety. Numerous sensitization seminars and workshops were held for designers and practicing engineers.

The activities mentioned above and other numerous activities undertaken by GSDMA for risk reduction in Gujarat including Ahmedabad Municipal area are outlined in detail in various publications and reports of GSDMA (GSDMA 2002b, 2003, 2005b), but this paper will focus on the initiatives related to urban vulnerability reduction.

A case in point is the amendments undertaken by Government of Gujarat in the GDCR, on the suggestion of government of India ${ }^{7}$, by appointing a technical committee of experts on $9^{\text {th }}$ February (within two weeks of the earthquake) to suggest changes in the development control regulations dealing with grant of permissions for construction of buildings. The state government also suspended the issue of grant of building permissions throughout the state till the amendment of the GDCR. The initial order issued based on the recommendations of the committee on $27^{\text {th }}$ March 2001 was revised through a consultative process by holding a meeting with various stakeholders who made representations ${ }^{8}$ regarding implementation of certain provisions of the order. The final orders were issued on $29^{\text {th }}$ May 2001, to include regulations related to structural design as per National Building Codes and Indian Standards Specifications.

Though the final order for amendments was issued through a process of consultation, one of the important factors for acceptance of the Suo Moto order of the government, issued for the first time in contrast to the normal procedure, ${ }^{9}$ was the suspension of building permissions till the revision of GDCR. The other important factor was the police cases filed against the builders and professionals after the earthquake and opinions of the experts regarding lack of regulation and enforcement as the main cause of building failure in urban areas.

Major changes to plug the loopholes in GDCR were brought through amendments. The method of calculation of FSI was revised and the exemption given for open spaces and

\footnotetext{
${ }^{7}$ Government of India wrote to the state government on $2^{\text {nd }}$ February ( immediately after the earthquake), to urgently put in place a techno-legal regime for buildings through necessary modifications in building bye-laws \& regulations, land use zoning and development control regulations and town planning acts. Government of India was aware of the problems of urban vulnerability even before the occurrence of Gujarat earthquake. Vulnerability atlas of India was prepared by Ministry of Urban Development in 1997, and the Ministry also came up with a report prepared by experts in 1998 for urban vulnerability reduction through changes in the physical planning process, development control regulations and town planning acts as a follow up of Yokohama strategy for safer habitat.

${ }^{8}$ Representations were made by Gujarat Urban Development Authorities Association, Institute of Architects, and Association of engineers, Association of consulting engineers and Municipal Corporations.

${ }^{9}$ The usual procedure for amendment in GDCR is that the concerned development authority passes a resolution suggesting changes and sends the same to the Urban Development Department. The Department publishes the same and invites objections and suggestions from the stakeholders. Based on the objections received, the department, if necessary makes changes in the proposal and after due process the final order is issued. This time consuming quasi-legal procedure was cut short for the revision of GDCR after the earthquake, Government invoked the powers vested with it under section 122 of the Gujarat Town Planning and Urban Development Act 1976 and issued orders on $29^{\text {th }}$ May 2001 bringing the amendments in to effect from the date of publication of the order.
} 
balconies were withdrawn. The power to condone FSI violations was cancelled. The roles and responsibilities of the structural engineer, engineer, architect, site supervisor and the builder have been defined. The requirement of structural safety in terms of IS codes for seismic, wind and fire safety, and quality control requirements were clearly spelt out in the GDCR. Mandatory zoning and land use based on hazards have been introduced for vulnerability reduction. Qualifications for registration of engineers have been amended. A provision of registration of builders/ developers has been made.

Changes have been made in the processes also. For ensuring structural safety, as per the amended GDCR, the certificate of undertaking needs to be signed by the builder, structural engineer and the architect. It is mandatory to submit the structural drawings of the building and completion certificate jointly signed by the structural engineer and the architect while applying for occupancy certificate. Federation of Real Estate Developers Association of Gujarat voluntarily adopted a code of conduct on $9^{\text {th }}$ May 2003 to ensure building safety and quality. Gujarat Professional Civil Engineers Act 2006 was passed in the Gujarat Legislative assembly to empower the engineers and to set up an engineering council for testing the competency of engineers and issue licenses, replacing the system of registration of engineers with the Municipal Corporations.

In India, the situation of engineers is different from that of other professionals. The professions of medicine, law, charted accountancy, and architecture are governed by legislations that provide legal status and regulate these professions. There is no such legislation for civil engineers and the profession is quite disorganized. There is no licensing system in the country for structural engineers and any person with a degree in Civil Engineering can generally practice as one. Thus there is no mechanism for the client to ensure that the engineer involved in the project is indeed competent in general and in seismic engineering in particular (EERI 2002). As there was no initiative at the level of Government of India for the setting up of an engineering council at the national level by passing an act in the parliament, Government of Gujarat took the initiative to set up the engineering council of Gujarat to ensure safety, accountability and to encourage high standard of engineering.

GSDMA, after many rounds of consultations with the practicing engineers, engineering colleges, and consulting firms prepared the prepared the draft bill. The process which was initiated in 2003, took three years to pass through consultations, correction, and legal scrutiny before it could be placed in the Legislative assembly for approval. Despite the consultations held and consensus arrived before passing of the bill, the engineering community is reluctant to take up the responsibility and thus the creation of the council has not taken place even after one year of passing of the Act. It appears as though, the engineering community, while wanting empowerment, is not willing to take responsibility that goes along with it.

\section{Regulations and beyond:}

\subsection{Regulation and enforcement}

All the stakeholders agree that the quality of construction has improved, builders/developers, engineers and architects have become more responsible and municipal engineers have also become more cautious. The very fact that a copy of the structural drawing of the building will be in the custody of Municipal authorities has created a sense of caution among the engineering community (Patel 2007a). According to many structural engineers more than 90 
percent of the post-earthquake constructions are safe and despite the increase in construction cost, people are willing to pay considering the fact that the cost escalation is due to factoring of earthquake resistant design in the construction (Patel 2007b)

Is Ahmedabad safe today, after six years, compared to what it was before the earthquake? The question is difficult to answer for two reasons. One important reason is the existence of a large number of unsafe buildings constructed before the earthquake, but not damaged in the earthquake. The other reason is the absence of a mechanism of verification of the safety of buildings constructed after the earthquake.

In the amended GDCR also, the responsibility for enforcement of the building codes and safety provisions is still with the developer, architect, engineer and structural designer. There is no system of enforcement, and the system of self regulation continues. As abundant caution, everybody has been made responsible for everything. Yates attributes (2002:4-8) consensual neglect, regulatory over load, cutting corners, inadequate resources for enforcement, penalties little known and inappropriate mechanism as the reasons for non enforcement of regulation.

Third party audit for enforcement of quality and structural safety is one of the mechanisms which will enable enforcement in case of mega cities like Ahmedabad where there is regulatory over load and inadequate resources for enforcement. Third party verification of structural design for specified buildings has been made mandatory in Delhi Municipal Corporation. In Bombay Municipal Corporation a high rise committee has been constituted to pass buildings of 70 meters and above in height (Sheth 2007). The system of registration of engineers based on experience should be replaced by a system of competency based registration. Engineering council should be set up to quickly to issue licenses to engineers based on competency. The system of registration of builders is yet to be implemented.

In order to enforce compliance, prosecutions for failing to comply actually have to occur and be seen to occur (Yates 2002). Regarding penalties, it is not the severity of punishment which will reduce violations, but only certainty of punishment will reduce the violations. Clarity of roles and responsibilities in regulation is needed to punish violations.

GDCR has been amended to include proper land use planning and integration of safety planning with spatial planning. Along with the enforcement of prohibition of settlements and restriction of settlements in the hazard prone areas, the housing needs of the urban poor should also be considered. Unless conscious efforts are made to tackle the housing problem of urban poor, illegal housing development in hazard prone areas cannot be prevented. Development of alternative sites (Tipple 2005), and provision of affordable housing for the poor should also be given priority to avoid settlements in hazard prone areas.

\subsection{Regulation and transparency}

Implementation of Hazard mitigation relies heavily on the individuals in the design and building professions (Godschalk et al. 1999). In the present system professionals are not part of the enforcement mechanism. Professionals should be made partners in enforcement of regulations by empowering them and making them more responsible and accountable. AMC should avoid the all or none approach regarding the safety of the buildings and concern itself only with buildings of certain critical nature and ensure safety through a system of third party audit. In order to avoid consensual neglect, practicing professionals and experts should be 
made part of the committee for drafting the GDCR. The discretionary powers of granting exemptions and condoning violations should not vest with any individual and it should vest with a committee consisting of members of professional bodies, civil society representatives and experts.

The town development department should be restructured to meet the emerging challenges of vulnerability reduction. The present system holds every one responsible for everything without any role clarity and when it comes to actually fixing responsibility, nobody can be really held responsible for anything. A system of clear roles and fixed responsibilities should be evolved to make the department more accountable. There is also need for capacity building by providing techno-legal training before a new job is assigned to an engineer through transfer or promotion. The current system of promotions and assignment of responsibility is not based on capabilities, merit and educational qualifications. One can join the department as a sub-inspector with a diploma and rise up to the level of Town Development Officer (Head of the Department) through seniority based promotion. A system of lateral entry for people with higher qualifications and merit based seniority will ensure that qualified personnel occupy responsible posts. In the current system the city is divided into wards and zones and inspection of all the buildings in the ward regardless of the size, height and utility of the buildings in the ward is done by the designated inspector of the ward. There is a need for restructuring the department to ensure that critical buildings and buildings of certain categories are inspected by more qualified and technically competent engineers of the department. Transparency, not only in dealings with public but also within the department is essential to ensure the effectiveness of the enforcement mechanism.

People have a right to feel protected in their communities, yet equally they need to be aware of their shared responsibility to protect themselves (Lewis and Mioch 2005). Information, education and communication activities should be taken up on a large scale to educate people about hazards, vulnerability and minimum safety requirements. Enlightened consumer is an empowered consumer who can create a market for safe structures and enforce compliance through market.

\subsection{Regulation and Rating}

The buyer of a house or flat, as said earlier is not aware of all the technical requirements of an earthquake resistant building. Even if the consumer is aware of the requirements of IS a code for seismic safety he has no way of knowing if the building has been constructed according to the codes and if quality control has been taken care of. The present system of self-regulation cannot assure the public about the safety of the building. In many products government provides a choice to the consumers through certification by Bureau of Indian Standards and in products which have health and safety implications ISI certification is mandatory. Without a mechanism to inform the buyers about the quality and safety of the buildings the consumers are at the mercy of the developers without any choice.

The developers due to their knowledge and understanding of the field of real estate stand at an advantage, and exploit the loopholes in the system to maximize their profit, while the less informed customer is at a more disadvantageous end (Preethi 2005). Preethi in her thesis suggests a credit rating for developers based on track record, project management capability, financial risk profile, number of projects in hand etc by an independent credit rating agency such as Credit Rating Information Services of India Ltd (CRISIL). While rating of builders will help people to buy houses or Flats from a highly rated builder with confidence, it is not a 
quality and safety rating of the structures. Quality and safety certificate will have cost implications. Can there be a safety rating of the buildings? Should it be optional or mandatory? These are issues for further research.

\subsection{Regulation and compliance}

Hyogo framework of action (UNISDR 2005) urges the governments to adopt, or modify wherever necessary, legislation to support disaster risk reduction, including regulations that encourage compliance and that promote incentives for undertaking risk reduction and mitigation activities. Regulation which has utter disregard for market is bound to fail and hence the system should be made responsive to the market forces. Huge stock of unsafe buildings exists today in Ahmedabad. The existing building stock cannot be made safe by regulations for retrofitting. Only a system of encouragement in the form of incentives and tax benefits can motivate owners to undertake retrofitting to reduce vulnerability. Structural safety can be linked with insurance premium and reverse mortgage.

Improving market based control mechanisms such as taxation and pricing (Munasinghe and Clarke 1995), reduction of insurance premiums and lesser deductibles for building constructed as per building codes, low- interest loans for retrofitting of unsafe buildings, reducing adverse selection by promoting insurance as a mandatory requirement for loans and mortgages (Munasinghe and Clarke 1995) are some of the steps that can be undertaken to enforce the regulations indirectly. In order to increase the awareness of consumers and public, massive awareness campaigns can be started by providing information regarding hazards to all the individuals in the hazard prone areas or by providing a hazard map of the area to every household, clearly indicating the mitigation measures to be undertaken including safe construction practices.

In the aftermath of massive disasters the Aid Industry steps in and large amount of national and international aid pours into the affected areas resulting in too much of aid. In fact most of the donors can shift their humanitarian aid focus from post-disaster relief to pre-disaster mitigation and fund retrofitting of unsafe structures, information campaigns, and promotion of safe construction practices through civil society involvement. International donor bodies, government officials, NGOs, and the private sector need to focus their collective energies to create a safer world for urban dwellers through a series of innovative approaches for vulnerability (Parasuram and P.V 2000).

Though willful non-compliance of regulations is one of the reasons for vulnerability, there are many other reasons for non-compliance of norms. Regulation and enforcement are necessary, but what is needed is an enabling environment for the stakeholders to follow the regulations. Creation of an enabling environment goes beyond regulations and enforcement to address the issues of transparency, accountability, partnerships and market forces. The principles of good urban governance is the key for disaster mitigation and management (Lewis and Mioch 2005) and to build a culture of safety where disaster planning and management is accepted as part of normal life (Parasuram and P.V 2000)).The system should be made more compliant. The sensibility of the system should bring majority of the stakeholders in to a mode of willing compliance without the need for penal action. 


\section{Conclusion}

Gujarat Earthquake is a pointer not only towards the problems of urban vulnerability but also towards the need for a total systemic change in town planning and urban development in Gujarat. Regulation and enforcement of seismic codes are essential for creating a safe built environment and to reduce physical vulnerability in urban areas. But failure of enforcement of regulation should not lead to creation of more regulations. There is no guarantee that the same mechanism which failed to enforce the existing regulations will be able to enforce additional regulations. Not only regulation and enforcement is central to politics (Leftwich 2004) but lack of regulation and enforcement can also be politics. One has to understand the causes for the failure of enforcement and the politics of lack of enforcement, which resulted in a win-win situation for all the stakeholders: the authorities could avoid the regulatory overload, the builders maximized their profits and the public got houses at lesser costs. Every body seemed to be a winner till the occurrence of the earthquake. Lack of clearly spelt- out punitive measures, long drawn judicial process, and lack of civil society demand for safety compounded the problem of vulnerability.

The case study of Ahmedabad indicates that without addressing the fundamental issues which fail to create an environment of compliance, enforcement of regulations is not possible. Vulnerability reduction for earthquakes is not only a technical problem but also a legal, political and socio-economic problem which needs a holistic approach beyond regulations.

\section{References}

AUDA. 2004. Ahmedabad Urban Development Area: General Development Control Regulation, edited by U.D.A.U.H. Department: Ahmedabad Urban Development Authority.

Bakeri, Anil. 2007. Interview with the author on 3rd April 2007. Ahmedabad (Hand written record in possession of the author).

Boulle, Philippe, Luc Vrolijks, and Elina Palm. 1991. Vulnerability Reduction for Sustainable Urban Development. Disasters 5 (3):179-188.

Census Commission of India. 2007. Rural-Urban Population-India and States/Union territories:2001 2001 [cited 6th April 2007]. Available from http://www.censusindia.net/results/rudist.html.

Comerio, Mary C. 1998. Disaster Hits Home: New Policy for Urban Housing Recovery. Berkeley: University of California Press.

EERI. 2002. 2001, Bhuj, India Earthquake Reconnaissance Report

Earthquake Spectra Supplement to volume 18:1-398.

Godschalk, David R, Timothy Beatley, Philip Berke, David J Brower, and Edward J Kaiser. 1999. Natural Hazard Mitigation : Recasting Disaster Planning Policy And Planning. Washington, D.C: Island Press.

Goel, Rakesh K. 2007. Performance of Buildings During the January 26, 2001 Bhuj Earthquake 2002 [cited 1st April 2007].

Government of India. 2007. Ahmedabad Census 2001. Director of Census Operations Gujarat 2007 [cited 8th April 2007]. Available from http://censusgujarat.gswan.gov.in/2001/Paper-1/Paper-1_02.htm.

GSDMA. 2002a. 26th January, 2002:Gujarat Epicenter of Progress. Gandhinagar: GSDMA. 2002b. From tears to smiles: A 500 day saga of change. Gandhinagar: GSDMA. 2003. Beyond reconstruction. Gandhinagar: GSDMA.

. 2005a. Gujarat State Earthquake Management Plan, edited by GSDMA: GSDMA. 2005b. Grit and Grace: The story of reconstruction. Gandhinagar: GSDMA. 2006. Disaster Management: GSDMA.

2007. Quarterly progress report-October-December 2006, edited by GSDMA.

Jain, Sudhir K. 2005. The Indian Earthquake Problem. Current Science 89 (9):1464-1466. 2007. Personal Communication, 13th May.

Jain, Sudhir K, CVR Murti, Jaswant N Arlekar, Ravi Sinha, Alok Goyal, and CK Jain. 1997. Some Observations on Engineering Aspects of the Jabalpur Earthquake of 22 May 1997. EERI Special Earthquake Report, EERI Newsletter 32 (2):1-18. 
Jain, Sudhir K, CVR Murty, and Navin Chandak. 1994. The September 29,1993, M6.4 Killari, Maharashtra Earthquake in Central India. EERI Special Earthquake Report, EERI Newsletter 28 (1).

Key, David. 1990. Earthquake Design Practice for Buildings. London: Thomas Telford Limited.

Leftwich, Adrian, ed. 2004. What is Politics? Cambridge UK: Polity Press.

Lewis, Dan, and Jaana Mioch. 2005. Urban Vulnerability and Good Governance. Journal of contingencies and crisis management 13 (2):50-53.

Menum, Charles, and Ravi Mistry. 2001. The January 2001 Gujarat Earthquake. The John A.Blume Earthquake Engineering Center summer 2001 (27).

Mishra, P. K. 2004. The Kutch Earthquake 2001; Recollections, Lessons and Insights. New Delhi: National Institute of Disaster Management.

Mistry, Ravi, Weimin Dong, and Haresh Shah. 2001. Interdisciplinary Observations on The January 2001 Bhuj, Gujarat Earthquake: World Seismic Safety Initiative.

Munasinghe, Mohan, and Caroline Clarke, eds. 1995. Disaster Prevention For Sustainable Development. Washington D.C: World Bank,.

Murty, CVR, Marjorie Greene, Sudhir Jain, N Purendra Prasad, and Vipul Mehta. 2005. Earthquake Rebuilding in Gujarat, India: An EERI Recovery Reconnaissance Report. Oakland CA: Earthquake Engineering Research Institute.

National Crimes Record Bureau. 2007. Accidental Deaths In India 2007 [cited 8th April 2007]. Available from http://ncrb.nic.in/adsi2005/accident05.pdf.

Oyo Corporation. 2004. Feasibility Study on Seismic Microzonation in Gujarat: Oyo Corporation, Tokyo, Japan.

Parasuram, S., and Unnikrishanan P.V, eds. 2000. India Disastr Report:Towards a policy initiative. New Delhi: Oxford University Press.

Patel, Alpesh. 2007b. Interview with the author on 7th May 2007. Ahmedabad, 7th May 2007.

Patel, Bimal, and Douglas. Walker. 2002. Reform of the development regulation system in Gujarat. Gandhinagar: GSDMA.

Patel, Bimal. 2007a. Interview with the author on 3rd April 2007. Ahmedabad (Cassette recording in possession of author).

Pelling, M. 2003. The Vulnerability of Cities: Natural Disaster and Social Resilience. London: Earthscan.

Preethi, Saraswathula. 2005. Rating Mechanism in Real Estate: Applicability \& Adaptability

Unpublished Thesis, School of Planning, CEPT, Ahmedabad.

Quarantelli, E L. 2003. Urban Vulnerability to Disasters in Developing Countries:Managing Risks. In Building Safer Cities: The Future of Disaster Risk, edited by A. Kreimer, M. Arnold and A. Carlin. Washington, DC: World Bank.

Shapiro, Daniel, Eling White Alquist, Donald O Manning, and Andrew A Andelman. 2000. Seismic Safety Commission Findings: A Report to the Governor and Legislature on Lessons Learned from Recent Earthquakes In Turkey, Greece, and Taiwan. Sacramento, CA: Seismic Safety Commission.

Sheth, Alpa. 2007. High rise committee. Gandhinagar, 8th April 2007.

Times of India. 2001. Forgotten Scam. Times of India.

Tipple, Graham. 2005. Housing and Urban Vulnerability in Rapidly- Developing Cities. Journal of contingencies and crisis management 13 (2):66-75.

UNDP. 2007. Urban earthquake vulnerability reduction project-India 2002 [cited 31st March 2007]. Available from http://www.undp.org/bcpr/documents/dru/proj_fact/FactsheetINdiaEarth quake_final.pdf.

UNISDR. 2005. Hyogo Frame work for Action 2005-2015: Building Resilience of Nations and Communities to Disasters. Paper read at World Conference on Disaster Reduction 18-22 at Kobe, Hyogo, Japan.

Vatsa, Krishna S. 2001. The Bhuj Earthquake District of Kutch, the state of Gujarat( India) January 26, 2001: A Reconnaissance Report — Identification of priority issues: DRM-World Institute for Disaster Risk Management.

Wamsler, Christine. 2006. Mainstreaming Risk Reduction in Urban Planning and Housing: A Challenge for International Aid Organizations. Disasters 30 (2):151-177.

Wisner, Ben, Piers Blaikie, Terry Cannon, and Ian Davis. 2004. At Risk: Natural hazards, people's vulnerability and disasters. Second edition ed. London: Routledge. Original edition, 1994.

Yates, Athol. 2002. The nexus between regulation enforcement and catastrophic engineering failures. In Current Issues in Regulation: Enforcement and Compliance. Melbourne. 